\title{
The Rheic Ocean: Origin, Evolution, and Significance
}

R. Damian Nance, Department of Geological Sciences, 316 Clippinger Laboratories, Ohio University, Athens, Ohio 45701, USA, nance@ohio.edu; Ulf Linnemann, Staatliche Naturhistorische Sammlungen Dresden, Museum für Mineralogie und Geologie, Königsbrücker Landstraße 159, D-01109 Dresden, Germany

\section{ABSTRACT}

The Rheic Ocean, which separated Laurussia from Gondwana after the closure of Iapetus, was one of the principal oceans of the Paleozoic. Its suture extends over 10,000 km from Middle America to Eastern Europe, and its closure assembled the greater part of Pangea with the formation of the Ouachita-Alleghanian-Variscan orogen.

The Rheic Ocean opened in the Early Ordovician, following protracted Cambrian rifting that represented a continuum of Neoproterozoic orogenic processes, with the separation of several Neoproterozoic arc terranes from the continental margin of northern Gondwana. Separation likely occurred along a former Neoproterozoic suture in response to slab pull in the outboard Iapetus Ocean. The Rheic Ocean broadened at the expense of Iapetus and attained its greatest width $(>4000 \mathrm{~km})$ in the Silurian, by which time Baltica had sutured to Laurentia and the Neoproterozoic arc terranes had accreted to Laurussia, closing Iapetus in the process. Closure of the Rheic Ocean began in the Devonian and was largely complete by the Mississippian as Gondwana and Laurussia sutured to build Pangea. In this process, North Africa collided with southern Europe to create the Variscan orogen in the Devono-Carboniferous, and West Africa and South America sutured to North America to form the Alleghanian and Ouachita orogens, respectively, during the Permo-Carboniferous.

The Rheic Ocean has long been recognized as the major Paleozoic ocean in southern Europe, where its history dominates the basement geology. In North America, however, the Rheic has historically received less attention than Iapetus because its suture is not exposed. Yet, it was the Rheic Ocean that played the dominant role in creating the AppalachianOuachita orogen, and an important record of its history may be preserved in Mexico.

\section{INTRODUCTION}

The Rheic Ocean-named for the Titan, Rhea, sister to Iapetus in Greek mythology-is arguably the most important ocean of the Paleozoic. Following the Silurian closure of the Iapetus Ocean, the Rheic Ocean separated the major paleocontinents

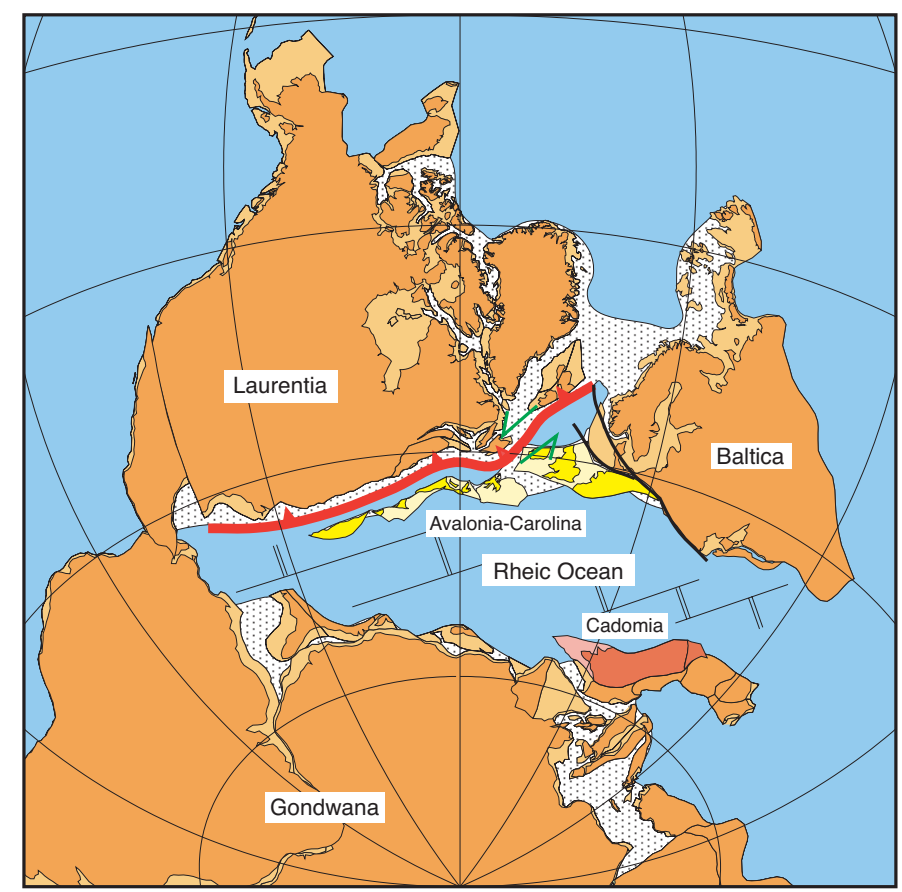

Figure 1. Early Silurian reconstruction of the Rheic Ocean immediately prior to the closure of lapetus by way of subduction beneath Laurentia (toothed red line). Stippled areas denote inferred regions of thinned and/ or anomalous thickness of continental and arc crust (simplified after Pickering and Smith, 1995, with Cadomia placed adjacent to Gondwana). Rheic ridge-transform system is purely schematic. Heavy black lines trace Tornquist suture zone.

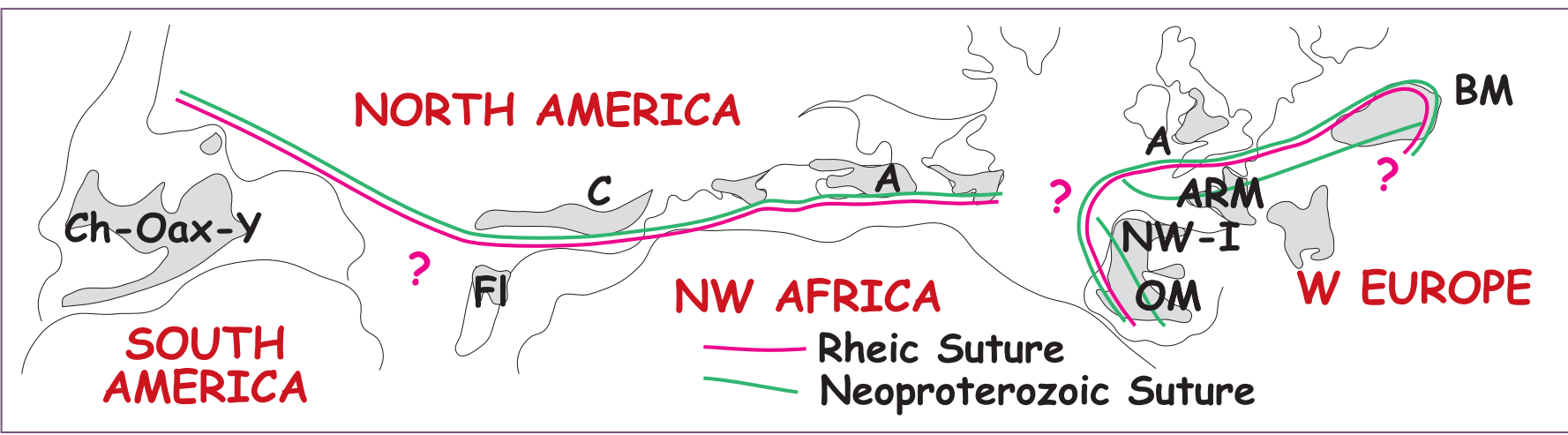

Figure 2. Location of Rheic suture on early Mesozoic reconstruction of the North Atlantic and its close correspondence with sutures associated with the accretion of arc terranes to the northern Gondwanan margin in the late Neoproterozoic (from Murphy et al., 2006). A-Avalonia; ARM-Armorica; BM—Bohemian Massif; C—Carolina; Ch—Chortis; Fl—Florida; NW-I—northwestern Iberia; Oax—Oaxaquia; OM—Ossa Morena; Y—Yucatán; question marks-areas where continuity of suture uncertain. 
of Laurussia (Laurentia-Baltica-Avalonia) from Gondwana (Fig. 1). Subsequent closure of the Rheic Ocean produced the Ouachita-Alleghanian-Variscan orogeny and assembled the supercontinent of Pangea.

The Rheic Ocean's importance has long been recognized in Europe, where its suture is well constrained and separate from that of the Iapetus Ocean to the north. Hence, in Europe, the Caledonide orogen, created by the closure of Iapetus, is a geographically distinct orogenic belt from the Variscan orogen, created by the closure of the Rheic Ocean. In North America, however, the two sutures follow a similar path, and the importance of the Rheic Ocean is often overlooked. Instead, the history of the Appalachian-Ouachita orogen is traditionally described in terms of the evolution of Iapetus, the opening of which is recorded in the late NeoproterozoicEarly Cambrian rifted margin of eastern and southern Laurentia and whose closure is documented in the accretion of a variety of peri-Gondwanan arc terranes in the Silurian (e.g., van Staal et al., 1998). The Rheic Ocean, in contrast, opened in the Early Ordovician with the separation of these periGondwanan arc terranes from the margin of northern Gondwana and closed with the collision of this margin with Laurussia during the Permo-Carboniferous assembly of Pangea (e.g., Murphy et al., 2006).

The lack of attention to the Rheic Ocean's role in the development of the Appalachian-Ouachita orogen is largely a function of geography. The orogen contains both the rifted margin and final suture of the Iapetus Ocean, and so preserves a complete record of its opening and closure. But it preserves no such margin of the Rheic Ocean, the suture of which lies buried beneath the sediments of the Coastal Plain outboard of the accreted peri-Gondwanan terranes or was removed with the opening of the Atlantic Ocean and the Gulf of Mexico. Nevertheless, the continent-continent collision that produced the Appalachian-Ouachita orogen in the late Paleozoic was the result of the closure, not of Iapetus, but of the younger Rheic Ocean, important vestiges of which may be preserved in Mexico.

This paper aims to correct this oversight by providing a review of the origin and evolution of the Rheic Ocean that demonstrates its significance to the geological history of both Europe and North America. The time scale used is that of Gradstein et al. (2004).

\section{EVOLUTION OF THE RHEIC OCEAN}

The initial rifting of the Rheic Ocean forms a continuum with the Neoproterozoic-Early Cambrian accretionary orogenic processes that preceded it. Rifting took place along the northern (African-South American) margin of Gondwana in the mid- to Late Cambrian, by which time Iapetus was already a wide ocean. Prior to this, in the late Neoproterozoic, the northern Gondwanan margin had witnessed a prolonged history of subduction and accretion followed in the Late Ediacaran-Early Cambrian by the diachronous cessation of arc magmatism and the development of a transform continental margin (e.g., Nance et al., 2008). This pre-rift history is analogous to that of the Pacific margin of North America in the Cenozoic, and the transition in tectonic regime along the Gondwanan margin has been similarly attributed to ridge-trench collision (e.g., Nance et al., 2002).

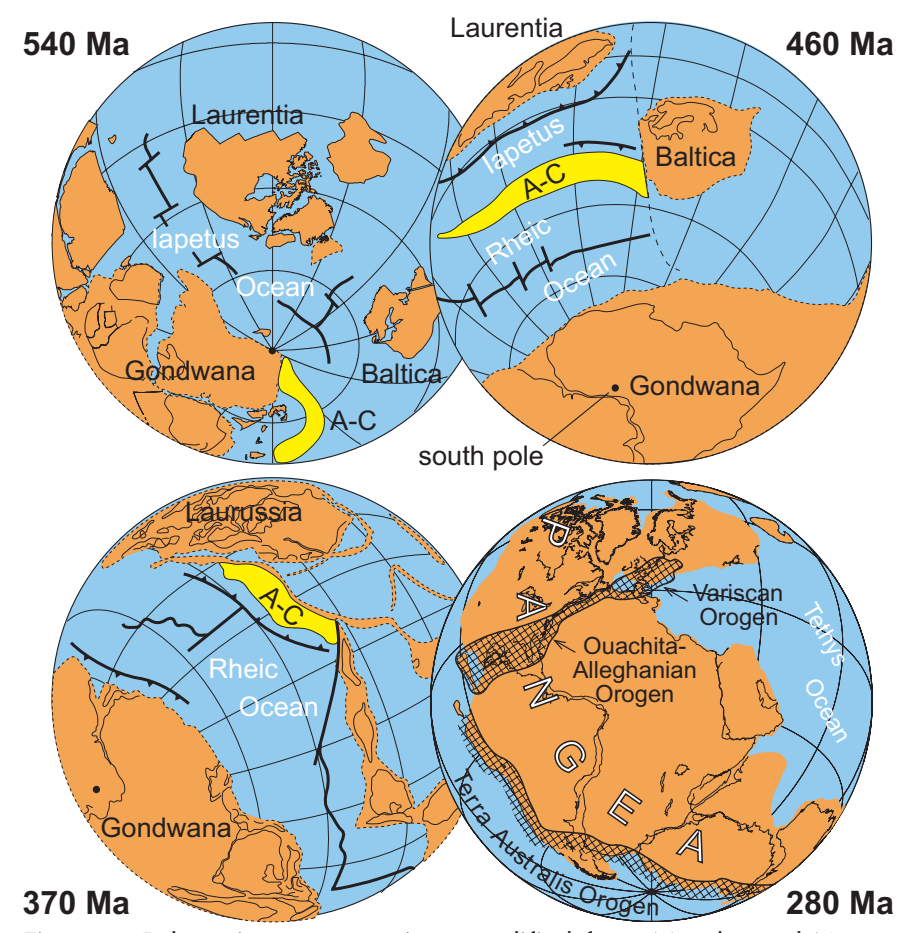

Figure 3. Paleozoic reconstructions modified from Murphy and Nance (2008). By $540 \mathrm{Ma}$, the lapetus Ocean had formed between Laurentia and Gondwana. By $460 \mathrm{Ma}$, Avalonia-Carolina (A-C) had separated from Gondwana, creating the Rheic Ocean. By 370 Ma, Laurentia, Baltica, and Avalonia-Carolina had collided to form Laurussia, and the Rheic Ocean began to contract, closing by 280 Ma to form Pangea.

Following protracted rifting, the Rheic Ocean opened in the Early Ordovician with the separation of several Neoproterozoic arc terranes from the margin of northern Gondwana. The micro-continental terranes that separated (e.g., Avalonia and Carolina) were the same terranes that had accreted to this margin in the late Neoproterozoic, leading Murphy et al. (2006) to suggest that separation occurred along the line of a former Neoproterozoic suture (Fig. 2).

In Europe, separation of Avalonia by Arenig time is supported by paleomagnetic data (e.g., Cocks and Torsvik, 2002) and $\mathrm{Sm} / \mathrm{Nd}$ isotopic studies of the sedimentary record (Thorogood, 1990), and is also recorded in the widespread deposition of the Armorican Quartzite. In Mexico, the onset of passive margin sedimentation occured in the latest Cambrian (Landing et al., 2007), whereas backstripped subsidence curves in eastern Avalonia suggest that drifting may not have been achieved until the mid-Arenig to Llanvirn (Prigmore et al., 1997). It is therefore likely that the rifting and separation of terranes from northern Gondwana took place diachronously. Also during this time, the Early Ordovician Gondwanan fauna of Avalonia were gradually replaced by endemic forms (Fortey and Cocks, 2003).

Throughout the Ordovician, the Rheic Ocean widened at the expense of Iapetus as Avalonia-Carolina drifted northward toward Baltica and Laurentia (Fig. 3). The endemic fauna of Avalonia were progressively replaced by those of Baltic and Laurentian affinities in the Llandeilo-Ashgillian (Fortey and Cocks, 2003), suggesting increasing proximity to these continents and a widening gap with Gondwana by the mid-Ordovician (ca. $465 \mathrm{Ma}$ ). Similarly, paleomagnetic data indicate that 


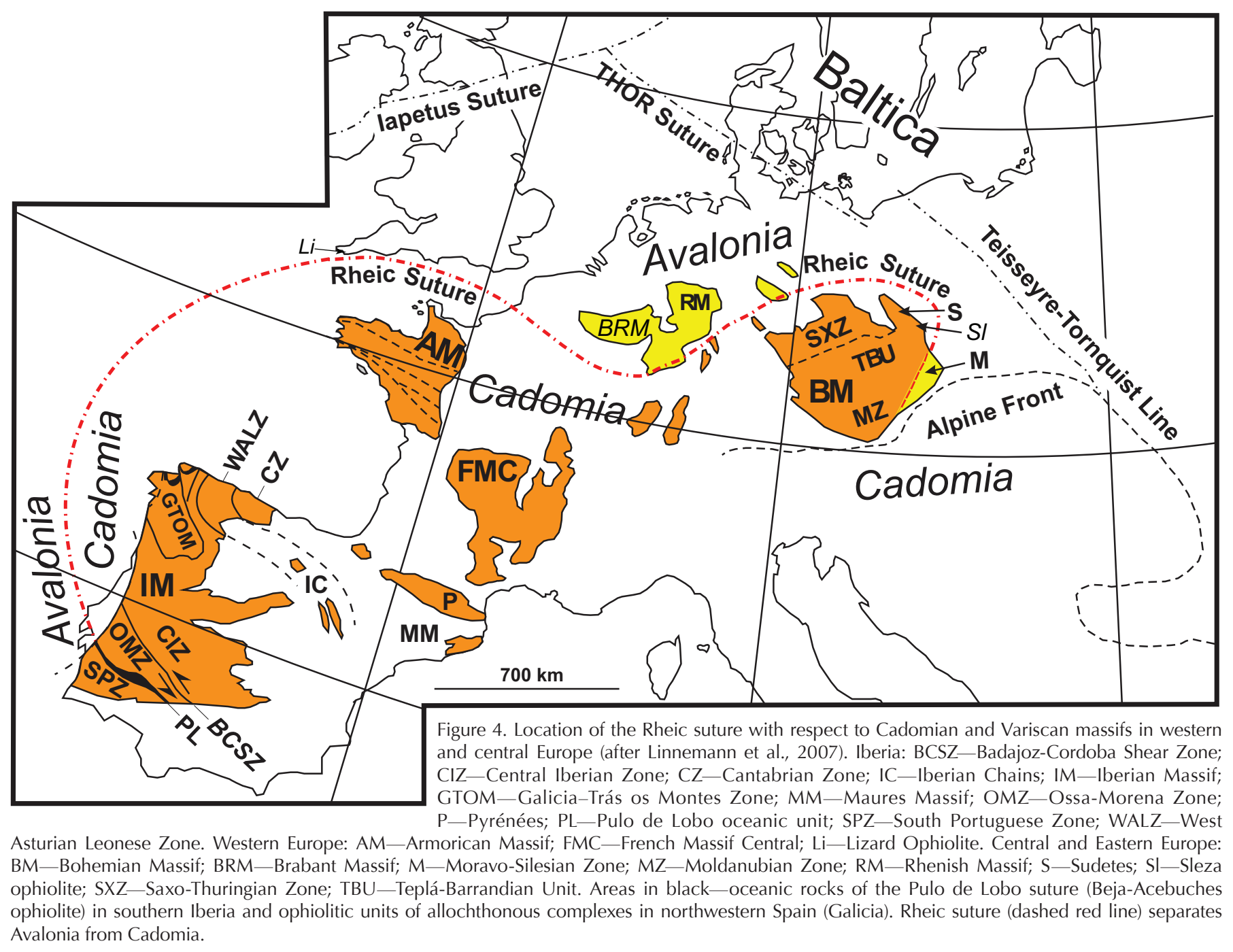

by $460 \mathrm{Ma}$ Avalonia lay at $41^{\circ} \mathrm{S}$ (Hamilton and Murphy, 2004), some 1700-2000 km south of Laurentia (at $20^{\circ} \mathrm{S}$; Mac Niocaill and Smethurst, 1994) and $2100 \mathrm{~km}$ north of Gondwana (at $\sim 60^{\circ} \mathrm{S}$; Cocks and Torsvik, 2002). This requires Avalonia to have drifted northward at the relatively rapid rate of $8-10 \mathrm{~cm} / \mathrm{yr}$. This is well in excess of modern ridge-push spreading rates (1-2 cm/yr), which suggests that the opening of the Rheic Ocean was likely driven by slab pull within the closing Iapetus Ocean to the north. Even faster rates may have been attained by Carolina, which was likely attached to, but $\sim 2000 \mathrm{~km}$ north of, Avalonia and minimally separated from Laurentia latitudinally by ca. $455 \mathrm{Ma}$ (e.g., Hibbard et al., 2002). European Cadomia (Fig. 1), also part of the active Neoproterozoic margin of Gondwana, likely remained on the northern Gondwanan margin, forming the southern margin of the Rheic Ocean from Lower Ordovician until at least uppermost Devonian times. This is supported by paleomagnetic data and the southerly paleolatitude of Cadomia in the Late Ordovician, indicated by widespread evidence for glaciation, which is characteristic of Gondwana but absent in Avalonia (e.g., Linnemann et al., 2004).

The Rheic Ocean reached its greatest width $(>4000 \mathrm{~km})$ in the Silurian (Fig. 1), by which time Laurentia had collided with Baltica to the north and with Avalonia-Carolina to the south, closing the Iapetus Ocean and creating the AppalachianCaledonide orogen. Closure of the Rheic began in the Early Devonian and was facilitated by northward subduction beneath the southern margin of Baltica in the Variscan belt, where arc magmatism developed on the previously accreted Avalonian terranes (e.g., Kroner et al., 2007), and by southward subduction beneath the northwestern margin of Gondwana in the Appalachian-Ouachita belt, where Laurentia forms the lower plate (Hatcher, 1989; Viele and Thomas, 1989). Closure was accompanied ca. 395-370 Ma by the emplacement of ophiolites in southern Britain and northwestern and southern Iberia, and may have accelerated as a result of ridge-trench collision along the ocean's northern margin (Woodcock et al., 2007). Closure was essentially complete by the Mississippian as Gondwana and Laurussia collided, a process that continued into the Early Permian. The sequential collision of Gondwana's West African margin with southern Baltica and eastern Laurentia created the Variscan and Alleghanian orogens, respectively, and reactivated the Mauritanides of West Africa (e.g., Piqué and Skehan, 1992), whereas Gondwana's Amazonian margin collided with southern Laurentia to produce the Ouachita orogen. The resulting Ouachita-Alleghanian-Variscan belt was the largest collisional orogen of the Paleozoic and sutured Gondwana and Laurussia to form Pangea (Fig. 3). 

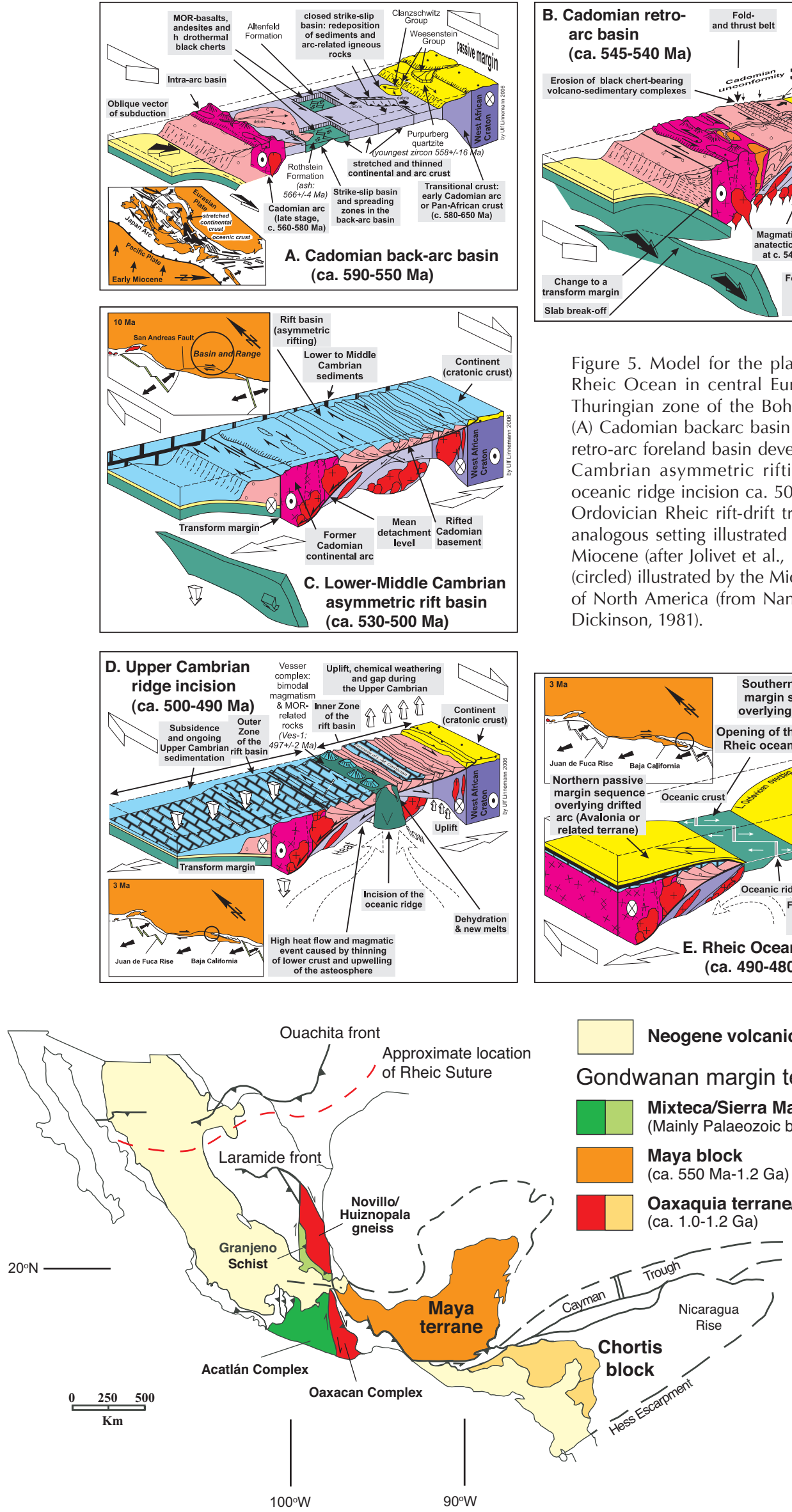

Figure 6. Simplified tectonic map of Gondwanan Middle America showing location of Mexico's Oaxacan Complex and Novillo Gneiss (Oaxaquia terrane), Acatlán Complex (Mixteca terrane), and Granjeno Schist (Sierra Madre terrane). Modified after Keppie (2004). 


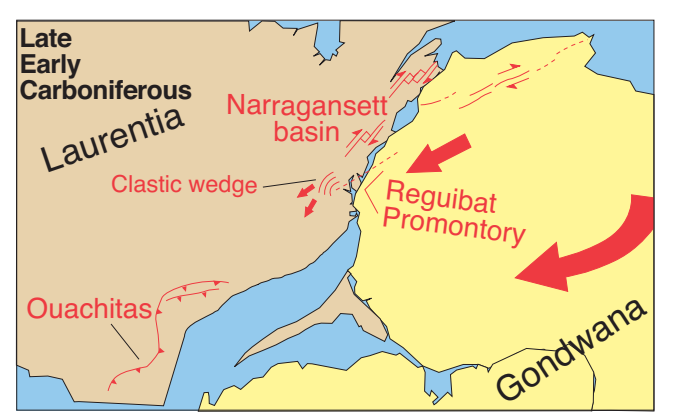

A

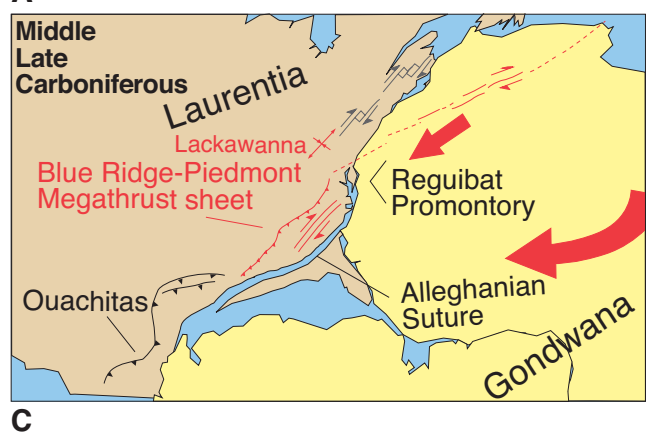

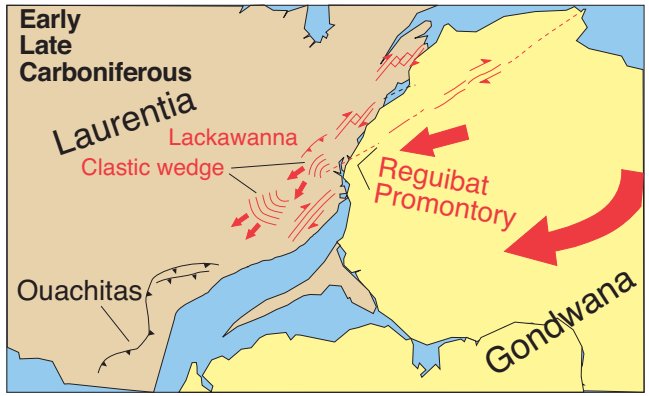

B

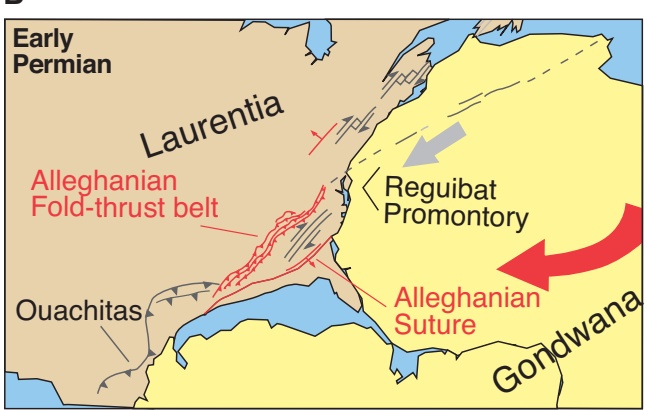

D
Figure 7. Oblique rotational collision between Laurentia and Gondwana according to Hatcher (2002). Symbols in red identify features active during time interval represented. (A) Initial contact between Laurentia and Gondwana during the late Mississippian. (B) Southward motion and clockwise rotation of Gondwana during the early Pennsylvanian. (C) Continued rotation and southward movement of Gondwana in the late Pennsylvanian. (D) Head-on Laurentia-Gondwana collision in the Early Permian.

\section{THE RHEIC OCEAN IN CENTRAL EUROPE}

The formation of the Rheic Ocean in Europe is closely linked to the termination of the late Neoproterozoic Cadomian orogeny (ca. 700-540 Ma), and its closure caused the Variscan orogeny. This closure, ca. 370-330 Ma, produced a suture (Fig. 4) that runs westward from the Mid-German Crystalline zone in Germany and the Lizard ophiolite in southern Britain to the Pulo do Lobo unit of southern Iberia. To the east, in the Bohemian Massif, the Rheic suture is documented by the Sleza ophiolite (e.g., Floyd et al., 2002) in the Sudetes and may extend to the Moravo-Silesian zone on the massif's eastern margin (considered part of Avalonia; Finger et al., 2000) and on into Eastern Europe (Bulgaria, Romania, Turkey; e.g., Winchester et al., 2002).
In central and western Europe, the suture separates Cadomia and its Paleozoic passive margin from the southern margin of Laurussia as represented by the eastern part of Avalonia and its overlying Paleozoic strata. Important vestiges of the Rheic Ocean exist (1) in the Cornubian basins and Lizard ophiolite of southern Britain (e.g., Nutman et al., 2001); (2) in the development ca. $500 \mathrm{Ma}$ of a passive margin sequence and emplacement ca. $340 \mathrm{Ma}$ of ophiolitic allochthons in northwestern Iberia (e.g., Sánchez-Martínez et al., 2007); (3) in the well-documented rift succession of the Ossa-Morena Zone (e.g., Sánchez-García et al., 2003) as well as the Pulo do Lobo accretionary prism and Beja-Acebuches ophiolite in southern Iberia (Quesada et al., 1994); and (4) in the evidence of an Early Ordovician breakup unconformity and widespread sub-

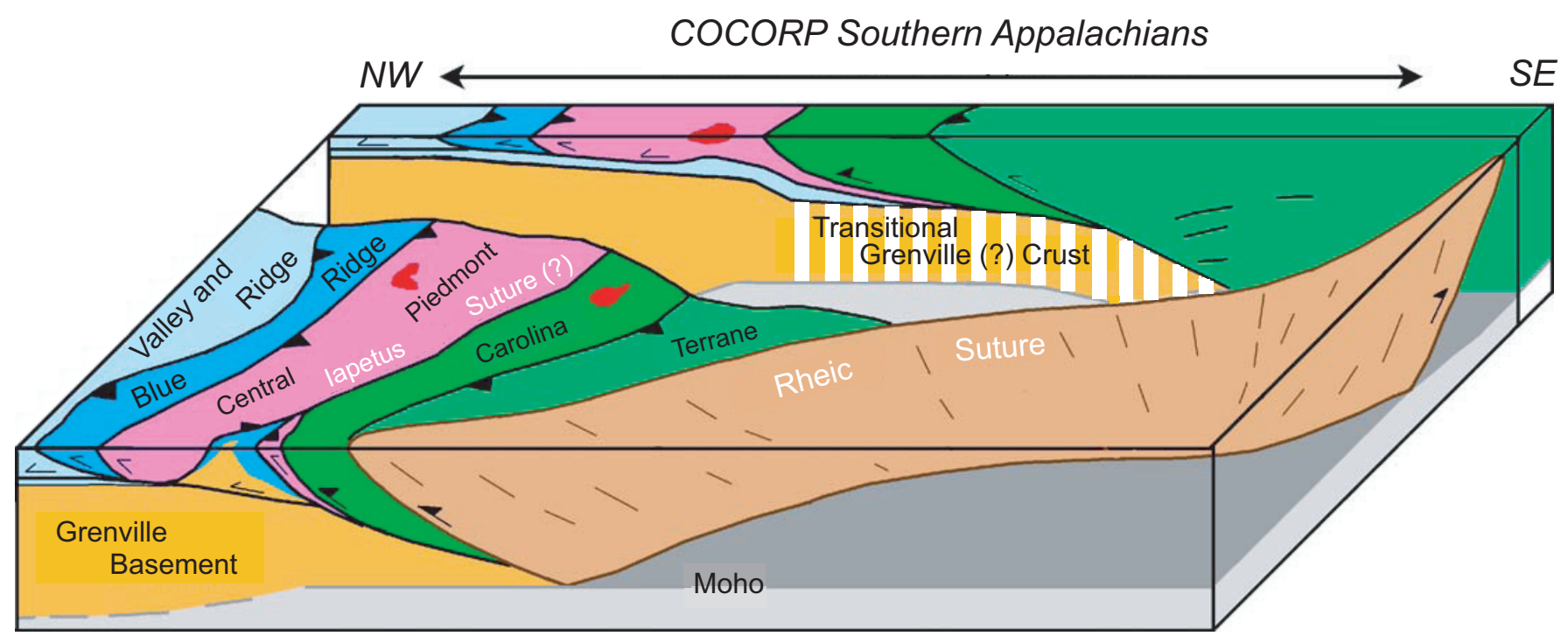

Figure 8. Schematic block diagram of the crustal structure of the southeastern Appalachians based on reprocessed data from the Consortium for Continental Reflection Profiling (COCORP) reflection survey (modified from Cook and Vasudevan, 2006). 
sidence indicated by the distribution of the Armorican Quartzite across Iberia and northwestern France. We focus here, however, on the northern Bohemian Massif, where the record of the evolution of the Rheic Ocean is most complete. In this region (Fig. 4), the northern (Avalonian) margin of the Rheic Ocean is represented by the Brabant and Rhenish massifs (Rhenohercynian zone), the suture by the Mid-German Crystalline zone, and the southern (Gondwanan) margin by the northern Bohemian Massif (Saxo-Thuringian and Moldanubian zones).

\section{Rifting and Opening: Aftermath of the Cadomian Orogeny}

In western and central Europe, there is no sharp break between the Cadomian orogeny of the late NeoproterozoicEarly Cambrian and the Cambro-Ordovician rifting that led to the opening of the Rheic Ocean. Hence, the active margin processes that characterize the Cadomian orogen form an important precursor to the opening of the Rheic. The stages involved for the Saxo-Thuringian zone are summarized in Figure 5 (Linnemann et al., 2007).

The oldest (ca. 570-565 Ma) rocks in the Saxo-Thuringian zone are thought to record late Neoproterozoic backarc basin development on the active West African margin of Gondwana in a manner analogous to the present-day Sea of Japan (Fig. 5A). Subsequent inversion of this basin in the interval ca. $545-$ $540 \mathrm{Ma}$ is attributed to collision of the arc with the West African craton and the development of a short-lived backarc foreland basin (Fig. 5B). Granitoids emplaced ca. 540 Ma were likely derived from melting of the basin fill and are thought to record a pulse of high heat-flow that is attributed to slab break-off as a result of ridge-trench collision.

Following this event, the margin switched from active to transform, leading to the development of asymmetric rifts in the Lower and Middle Cambrian similar to those of the presentday Basin and Range Province (Fig. 5C). Subsequent ridge incision like that currently taking place in the Gulf of California is thought to be recorded in the oceanic rocks of the Upper Cambrian Vesser Complex (Fig. 5D).

Lower Ordovician deposits throughout the Cadomian part of central and western Europe are characterized by the Armorican Quartzite and its equivalents, which, in the Saxo-Thuringian zone, are $\sim 3000 \mathrm{~m}$ thick. These deposits overstep Lower to Middle Cambrian strata or lie directly on Cadomian basement (Fig. 5E), indicating significant thermal subsidence. Their deposition follows the final rift-related magmatism ca. $485 \mathrm{Ma}$ and is taken to record the opening of the Rheic Ocean and the separation of Avalonia from the Gondwanan margin.

From the mid-Upper Ordovician to mid-Devonian, the SaxoThuringian zone is characterized by relatively quiescent shelf sedimentation, consistent with its position on the southern passive margin of the Rheic Ocean. In places, sedimentation continued into the Lower Carboniferous, but by the Upper Devonian, Rheic Ocean closure had incorporated portions of the shelf into the developing Variscan orogen.

\section{Closure and Collision}

In Europe, the Rheic Ocean continued to expand until (1) Avalonia collided with Baltica ca. $450 \mathrm{Ma}$ with the closure of the Tornquist Sea along the Teisseyre-Tornquist Line (Fig. 4); and (2) Baltica-Avalonia collided with Laurentia to form Laurussia with the closure of the Iapetus Ocean. Closure of Iapetus was complete by the latest Silurian (e.g., Pickering, 2008), following which Avalonia became part of the Old Red Continent and was blanketed by Lower Devonian redbeds.

The onset of Rheic Ocean closure may be recorded in the Mid-German Crystalline zone by a Late Silurian to Lower Devonian (ca. 418-400 Ma) magmatic event that has been attributed to north-directed subduction beneath Laurussia following the closure of Iapetus (e.g., Kroner et al., 2007). Final closure of the Rheic Ocean in Europe is marked by the Variscan orogeny, which, in the Saxo-Thuringian zone and elsewhere, juxtaposed widespread Late Devonian to Early Carboniferous high-pressure metamorphic units (allochthonous domains) against lowgrade Cadomian and Paleozoic successions (autochthonous domains). Following destruction of the Rheic Ocean floor, oblique subduction of thinned Gondwanan continental crust began in the Early Devonian and persisted until the Early Carboniferous with early exhumation of Gondwanan high-pressure rocks ca. $370 \mathrm{Ma}$. These rocks were locally subducted to depths at which metamorphic diamond is stable $(\sim 120 \mathrm{~km})$. Southeast-directed exhumation was initially accommodated in the subduction channel, after which (ca. 340-330 Ma) regional dextral transpression, rapid exhumation of the rocks of the allochthonous domain, and filling and folding of flysch basins occurred. Related widespread Variscan plutonism occurred in the Bohemian Massif ca. 335-320 Ma. Consistent with this evolution, the Mid-German Crystalline zone, which defines the Rheic suture, records a Late Devonian-Early Carboniferous history of oblique subduction, collision, exhumation, and strikeslip tectonics.

\section{THE RHEIC OCEAN IN NORTH AMERICA}

Although the Rheic suture is not exposed in North America, closure of the Rheic Ocean in the late Paleozoic dictated the sedimentary and deformational history of the entire Ouachita-Appalachian orogen. Furthermore, important vestiges of the ocean's southern (Gondwanan) rifted continental margin and a possible record of its Late Devonian-Mississippian subduction are preserved in the Mixteca, Sierra Madre, and Oaxaquia terranes of southern and eastern Mexico (e.g., Nance et al., 2007).

\section{Rifting and Opening}

Within the Appalachians, evidence of the opening of the Rheic Ocean occurs only in those peri-Gondwanan terranes that defined the ocean's northern margin and that were accreted to Laurentia with the closure of Iapetus. In Avalonia, for example, minor bimodal rift volcanism, predominantly of Middle to Late Cambrian age but locally spaning the entire Cambrian (e.g., Greenough and Papezik, 1986), may record initial rifting.

Faunal data suggest that rifting was a protracted process. Distinct faunal provinciality in the Early Cambrian suggests that Avalonia and Gondwana were separate (e.g., Landing, 1996), although the seaway between the two was narrow because the separation is not detectable paleomagnetically (e.g., Van der Voo, 1988). By the Middle Cambrian, the faunal barrier had broken down and, in the Early Ordovician, the fauna of Avalonia are of Gondwanan affinity. Faunal provinciality and paleomagnetic data following the Early Ordovician document the 
increasing separation of Avalonia from Gondwana (e.g., Cocks and Torsvik, 2002).

In Mexico, vestiges of the Gondwanan continental margin of the Rheic Ocean are preserved in the Oaxaquia terrane, and voluminous bimodal magmatism that is interpreted to record rifting along this margin is present in the adjacent Mixteca terrane (Fig. 6). The Oaxaquia terrane, the largest exposed portions of which are the Oaxacan Complex and Novillo Gneiss, exposes Mesoproterozoic (ca. 1.0-1.2 Ga) basement (e.g., Keppie, 2004) unconformably overlain by latest Cambrian-Early Ordovician (Tremadocian) and mid-Silurian (early to mid-Wenlock) continental margin siliciclastics containing fauna of Gondwanan affinity (e.g., Boucot et al., 1997; Landing et al., 2007).

To the west, the Mixteca and Sierra Madre terranes are interpreted to contain vestiges of the Rheic Ocean juxtaposed against the Oaxaquia terrane along major north-south dextral faults of Early Permian age (Nance et al., 2007, and references therein). These vestiges form a major component of the Acatlán Complex, which constitutes the basement of the Mixteca terrane, as well as the Granjeno Schist of the Sierra Madre terrane to the north. In the Acatlán Complex, megacrystic granitoids and amphibolites of Ordovician age (ca. 440-480 Ma) intrude siliciclastic metasedimentary rocks (Piaxtla Suite) with detrital zircon signatures that closely match those of the early Paleozoic platform overlying the Oaxacan Complex (Gillis et al., 2005). The association is interpreted as a part of a protracted rift-passive margin sequence (e.g., Miller et al., 2007) analogous to the present-day Gulf of California, in which rifting continued well beyond terrane separation. Predominantly low-grade siliciclastic rocks of pre-Carboniferous age are thought to represent either continental rise deposits laid down within the Rheic Ocean or trench deposits associated with its subsequent closure.

\section{Closure and Collision}

Subduction of the Rheic Ocean in the Late Devonian-Mississippian is thought to be documented in the Piaxtla Suite of the Acatlán Complex by eclogites and decompression migmatites with ages of ca. 345-350 Ma (Middleton et al., 2007) and by high-pressure rocks (including blueschists) with ages spanning the interval 320-345 Ma (Vega-Granillo et al., 2007). Associated arc rocks are not preserved, nor are they present in the Ouachita orogen, where the arc is most likely to have accreted and where pyroclastic detritus and tuffs indicating the approach of an arc occur in rocks of Middle Mississippian age (e.g., Morris, 1989). Boulders of Devonian igneous and metamorphic rocks in strata of Pennsylvanian age (Dennison et al., 1977) may also attest to subduction in the outboard Rheic Ocean. The absence of an arc in Mexico has led Keppie et al. (2008) to suggest that, in this segment of the Rheic, the arc may have been removed by subduction erosion beneath the Oaxacan (Gondwanan) margin. Evidence of arc-related igneous rocks of DevonoMississippian age is likewise absent in the Appalachian orogen (e.g., Hermes and Murray, 1988), indicating that Laurentia, in contrast to Baltica, formed the lower plate during Rheic Ocean closure.

Closure of the Rheic Ocean resulted in the formation of the Ouachita belt and gave rise to the climactic phase in Appalachian orogenesis with the development of the Alleghanian orogen. Ocean closure was also responsible for the burial of the Laurentian platform, which was carbonate-dominated in the Mississippian, by thick Pennsylvanian clastic wedges that were shed westward (in the Appalachians) and northward (in the Ouachitas) into developing foreland basins from the rising orogenic front (e.g., Hatcher, 1989; Viele and Thomas, 1989). The onset of this clastic deposition took place in the Middle Mississippian, which, in the southern Appalachians, broadly coincides with the earliest ductile thrusting in the orogenic interior (ca. 335 Ma; Wortman et al., 1998).

Alleghanian deformation brought about by the collision of Gondwana and Laurentia likely involved oblique, rotational and orthogonal components and spanned the Pennsylvanian into the Early Permian (Fig. 7). In the northern Appalachians, Alleghanian orogenesis occurred as the result of oblique convergence between Laurentia and Gondwana and is dominated by dextral strike-slip tectonics on major northeast- and easttrending faults. In Canada, deformation is largely of Late Pennsylvanian age, and deposition was mainly confined to small wrench-related basins (e.g., Marillier, 1993). In New England, deformation was accompanied by Barrovian-style metamorphism that locally reached the sillimanite zone and has yielded cooling ages that span the Permian (e.g., Wintsch et al., 2003). Associated anatectic magmatism took place in the Late Carboniferous (ca. 325-305 Ma) and, more locally, in the Early Permian (ca. $275 \mathrm{Ma}$ ), presumably as the result of crustal thickening.

In contrast, in the Ouachitas and the central and southern Appalachians, the deformational architecture takes the form of crustal-scale décollement structures that verge north and west, respectively. Seismic profiling across the southern Appalachians (e.g., Cook and Vasudevan, 2006) shows these structures to be orogen-wide, with the Laurentian platform on the lower plate extending almost $100 \mathrm{~km}$ beneath the crystalline thrust sheets of the orogenic interior (Fig. 8). In this way, the foreland fold-thrust belts that are the hallmark of Ouachita-Alleghanian orogenesis and that first developed within the exposed Laurentian platform in the Early Pennsylvanian (e.g., Hatcher, 1989; Viele and Thomas, 1989) represent only the supracrustal toes of low-angle structures that originated in the mid-crust and rose in stair-step fashion to progressively higher crustal levels.

Post-Mississippian deformation in the orogenic hinterland of the southern Appalachians is accompanied by dextral strike-slip tectonics on northeast-trending ductile shear zones, and, as in New England, is associated with significant metamorphism and anatectic magmatism (e.g., Horton et al., 1987). Metamorphism locally reached the kyanite zone and records hornblende cooling ages of 320-295 Ma (Dallmeyer et al., 1986). Widespread granitoid magmatism of latest Mississippian-Pennsylvanian age (ca. 321-304 Ma; e.g., Samson, 2001) either accompanied or followed the metamorphism and, again, is probably the result of tectonic thickening of the crust in response to transpressive convergence between Laurentia and Gondwana (e.g., Hatcher, 2002).

In contrast, the Ouachita orogen is distinctive in that metamorphism is essentially absent and there is no associated magmatic activity. Where present, metamorphism is mostly of subgreenschist facies of poorly constrained Pennsylvanian to 
mid-Permian age (e.g., Viele and Thomas, 1989). Hence, the exposed portion of the orogen presumably lay well to the north of the Rheic suture. Following cessation of orogenic activity, this suture likely separated Laurentia from the Maya terrane (Fig. 6), which, prior to the opening of the Gulf of Mexico, is thought to have been contiguous with the Florida basement (e.g., Dickinson and Lawton, 2001).

\section{CONCLUSIONS}

As the ocean whose closure was responsible for the creation of the $>10,000 \mathrm{~km}$ Ouachita-Alleghanian-Variscan orogen and the assembly of the supercontinent of Pangea, the Rheic Ocean is arguably the most important ocean of the Paleozoic. Following the onset of subduction within the older Iapetus Ocean, the Rheic opened in the Early Ordovician as the result of the separation of Avalonia-Carolina from the northern margin of Gondwana along the line of a Neoproterozoic suture, likely in response to Iapetus slab pull. Records of this rifting and subsequent passive-margin development are preserved on the Gondwanan margin in the Oaxaquia and Mixteca terranes of southern Mexico, the Ossa-Morena zone of southern Spain, and the northern Bohemian Massif of central Europe. They are also preserved in Avalonia, the faunal and paleomagnetic records of which document the terrane's rapid northward drift toward Laurentia during the mid- to Late Ordovician.

The Rheic Ocean reached its maximum width (>4000 km) in the Silurian, following the accretion of Avalonia-Carolina to Laurentia and Baltica with the closure of Iapetus and the Tornquist Sea. Rheic Ocean closure began in the Early Devonian with subduction beneath both Baltica and northwestern Gondwana, and is recorded in the mid- to Late Devonian by ophiolite emplacement in southern Britain and northwestern and southern Iberia, and in the Late Devonian-Mississippian by eclogite facies metamorphism in Mexico and Europe.

By the Mississippian, closure was essentially complete, but it continued into the Early Permian as Gondwana's irregular West African margin collided with, and then moved westward and southward relative to, southern Baltica and eastern Laurentia, while its Amazonian margin converged with southern Laurentia. As a result, all three paleocontinents were sutured to form Pangea by the largest collisional orogenic belt of the Paleozoic. Closure of the Rheic Ocean played an unparalleled role in the sedimentary, structural, and tectonothermal record of the late Paleozoic from Central America to the Middle East and, with its completion, brought the Paleozoic era to an end.

\section{ACKNOWLEDGMENTS}

This paper is an outcome of International Geoscience Programme (IGCP) Project 497 awarded to Linnemann and Nance by the International Union of Geological Sciences and UNESCO. Nance additionally acknowledges U.S. National Science Foundation grant EAR-0308105 and an Ohio University Baker Award, and is indebted to Ibrahim Cemen for informative discussions on the Ouachitas. The authors are indebted to the remaining board members of IGCP Project 497-Erdin Bozkurt, Rob Stachan, Francisco Pereira, Maarten de Wit, Petr Kraft, Kerstin Drost, and Mandy Hofmann - and extend their thanks to all those who organized meetings, field trips, and special volumes in connection with this project. We also thank Margarete Patzak (UNESCO) and Sören Dürr (Deutsche Forschungsgemeinschaft [DFG-German Research Foundation]) for their help and support. Constructive comments by Peter Cawood and Gabi Gutiérrez-Alonso significantly improved the original manuscript.

\section{REFERENCES CITED}

Atwater, T., 1970, Implications of plate tectonics for the Cenozoic tectonic evolution of western North America: Geological Society of America Bulletin, v. 81, p. 3513-3536, doi: 10.1130/0016-7606(1970)81 [3513:IOPTFT]2.0.CO;2.

Boucot, A.J., Blodgett, R.B., and Stewart, J.H., 1997, European Province Late Silurian brachiopods from the Ciudad Victoria area, Tamaulipas, northeastern Mexico, in Klapper, G., Murphy, M.A., and Talent, J.A., eds., Paleozoic Sequence Stratigraphy, Biostratigraphy, and Biogeography: Studies in Honor of J. Grenville ("Jess") Johnson: Geological Society of America Special Paper 321, p. 273-293.

Cocks, L.R.M., and Torsvik, T.H., 2002, Earth geography from 500 to 400 million years ago: A faunal and palaeomagnetic review: Journal of the Geological Society, v. 159, p. 631-644, doi: 10.1144/0016-764901-118.

Cook, F.A., and Vasudevan, K., 2006, Reprocessing and enhanced interpretation of the initial COCORP Southern Appalachians traverse: Tectonophysics, v. 420, p. 161-174, doi: 10.1016/j.tecto.2006.01.022.

Dallmeyer, R.D., Wright, J.E., Secor, D.T., Jr., and Snoke, A.W., 1986, Character of the Alleghanian orogeny in the southern Appalachians: Part II. Geochronological constraints on the tectonothermal evolution of the eastern Piedmont in South Carolina: Geological Society of America Bulletin, v. 97, p. 1329-1344, doi: 10.1130/ 0016-7606(1986)97<1329:COTAOI>2.0.CO;2.

Dennison, R.E., Burke, W.H., Otto, J.B., and Heatherington, E.A., 1977, Age of igneous and metamorphic activity affecting the Ouachita folded belt, in Stone, C.G., ed., Symposium on the geology of the Ouachita Mountains, Volume 1: Arkansas Geological Commission, p. 25-40.

Dickinson, W.R., 1981, Plate tectonics and the continental margin of California, in Ernst, W.G., ed., The Geotectonic Development of California: Englewood Cliffs, New Jersey, Prentice-Hall, p. 1-28.

Dickinson, W.R., and Lawton, T.F., 2001, Carboniferous to Cretaceous assembly and fragmentation of Mexico: Geological Society of America Bulletin, v. 113, p. 1142-1160, doi: 10.1130/0016-7606(2001)113<1142:CTCAAF>2.0.CO;2.

Finger, F., Hanžl, P., Pin, C., von Quadt, A., and Steyrer, H.P., 2000, The Brunovistulian: Avalonian Precambrian sequence at the eastern Bohemian Massif: Speculations on palinspastic reconstruction, in Franke, W., Haak, V., Oncken, O., and Tanner, D., eds., Orogenic Processes: Quantification and Modelling in the Variscan Belt: Geological Society [London] Special Publication 179, p. 103-113.

Floyd, P.A., Kryza, R., Crowley, Q.G., Winchester, J.A., and Wahed, A., 2002, Sleza Ophiolite: Geochemical features and relationship to Lower Palaeozoic rift magmatism in the Bohemian Massif, in Winchester, J.A., Pharoah, T.C., and Verniers, J., eds., Palaeozoic Amalgamation of Central Europe: Geological Society [London] Special Publication 201, p. 197-215.

Fortey, R.A., and Cocks, L.R.M., 2003, Palaeontological evidence bearing on global Ordovician-Silurian continental reconstructions: Earth-Science Reviews, v. 61, p. 245-307, doi: 10.1016/S0012-8252(02)00115-0.

Gillis, R.J., Gehrels, G.E., Ruiz, J., and Flores de Dios Gonzaléz, L.A., 2005, Detrital zircon provenance of Cambrian-Ordovician and Carboniferous strata of the Oaxaca terrane, southern Mexico: Sedimentary Geology, v. 182, p. 87-100, doi: 10.1016/j.sedgeo.2005.07.013.

Gradstein, F.M., Ogg, J.G., Smith, A.G., Bleeker, W., and Lourens, L.J., 2004, A new Geologic Time Scale, with special reference to Precambrian and Neogene: Episodes, v. 27, p. 83-100.

Greenough, J.G., and Papezik, V.S., 1986, Acado-Baltic volcanism in eastern North America and Western Europe: Implications for Cambrian tectonism: Maritime Sediments and Atlantic Geology, v. 22, p. 240-251.

Hamilton, M.A., and Murphy, J.B., 2004, Tectonic significance of a Llanvirn age for the Dunn Point volcanic rocks, Avalon terrane, Nova Scotia, Canada: Implications for the evolution of the lapetus and Rheic Oceans: Tectonophysics, v. 379, p. 199-209, doi: 10.1016/j.tecto.2003.11.006.

Hatcher, R.D., Jr., 1989, Tectonic synthesis of the U.S. Appalachians, in Hatcher, R.D., Jr., Thomas, W.A., and Viele, G.W., eds., The Appalachian-Ouachita Orogen in the United States: Boulder, Colorado, The Geological Society of America, The Geology of North America, v. F-2, p. 511-535.

Hatcher, R.D., Jr., 2002, Alleghanian (Appalachian) orogeny, a product of zipper tectonics: Rotational transpressive continent-continent collision and closing of ancient oceans along irregular margins, in Martínez Catalán, J.R., Hatcher, R.D., Jr., Arenas, R., and Díaz García, F., eds., Variscan-Appalachian dynamics: The building of the late Paleozoic basement: Geological Society of America Special Paper 364, p. 199-208.

Hermes, O.D., and Murray, D.O., 1988, Middle Devonian to Permian plutonism and volcanism in the N American Appalachians, in Harris, A.L., and Fettes, D.J., eds., The Caledonian-Appalachian Orogen: Geological Society [London] Special Publication 38, p. 559-571.

Hibbard, J.P., Stoddard, E.F., Secor, D.T., and Dennis, A.J., 2002, The Carolina Zone: Overview of Neoproterozoic to Early Paleozoic peri-Gondwanan terranes along the eastern flank of the southern Appalachians: Earth-Science Reviews, v. 57, p. 299-339, doi: 10.1016/S0012-8252(01)00079-4. 
Horton, J.W., Sutter, J.F., Stern, T.W., and Milton, D.J., 1987, Alleghanian deformation, metamorphism, and granite emplacement in the central Piedmon of the Southern Appalachians: American Journal of Science, v. 287, p. 635-660.

Jolivet, L.M., Fournier, P., Huchnon, V.S. Rozhdestvenskiy, K.F.S., and Oscorbin, L.S. 1992, Cenozoic intracontinental dextral motion in the Okhotsk-Japan Sea region: Tectonics, v. 11, p. 968-977, doi: 10.1029/92TC00337.

Keppie, J.D., 2004, Mexican terranes revisited: A 1.3 Ga odyssey: International Geology Review, v. 46 p. 765-794 doi: 10.2747/0020-6814.46.9.765.

Keppie, J.D., Dostal, J., Murphy, J.B., and Nance, R.D. 2008, Synthesis and tectonic interpretation of the westernmost Paleozoic Variscan orogen in southern Mexico: From rifted Rheic margin to active Pacific margin: Tectonophysics, in press.

Kroner, U., Hahn, T., Romer, R.L., and Linnemann, U., 2007, The Variscan orogeny in the Saxo-Thuringian zone-heterogeneous overprint of Cadomian/ Palaeozoic peri-Gondwana crust, in Linnemann U., Nance, R.D., Kraft, P., and Zulauf, G., eds., The evolution of the Rheic Ocean: From AvalonianCadomian active margin to Alleghenian-Variscan collision: Geological Society of America Special Paper 423, p. 153-172.

Landing, E., 1996, Avalon: Insular continent by the latest Precambrian, in Nance, R.D., and Thompson, M.D., eds., Avalonian and Related Peri-Gondwanan Terranes of the Circum-North Atlantic: Geological Society of America Special Paper 304, p. 29-63.

Landing, E., Westrop, S.R., and Keppie, J.D., 2007 Terminal Cambrian and lowest Ordovician suc cession of Mexican West Gondwana: Biotas and sequence stratigraphy of the Tiñu Formation: Geological Magazine, v. 144, p. 909-936, doi: $10.1017 /$ S0016756807003585

Linnemann, U., McNaughton, N.J., Romer, R.L., Gehmlich, M., Drost, K., and Tonk, C., 2004 West African provenance for Saxo-Thuringia (Bohemian Massif): Did Armorica ever leave prePangean Gondwana?-U-Pb-SHRIMP zircon evidence and the $\mathrm{Nd}$-isotopic record: International Journal of Earth Sciences, v. 93, p. 683-705, doi: 10.1007/s00531-004-0413-8.

Linnemann, U., Gerdes, A., Drost, K., and Buschmann, B., 2007, The continuum between Cadomian orogenesis and opening of the Rheic Ocean: Constraints from LA-ICP-MS U-Pb zircon dating and analysis of plate-tectonic setting (Saxo-Thuringian zone, NE Bohemian massif, Germany), in Linnemann, U., Nance, R.D., Kraft, P., and Zulauf, G., eds., The evolution of the Rheic Ocean: From Avalonian-Cadomian active margin to Alleghenian-Variscan collision: Geologica Society of America Special Paper 423, p. 61-96.

Mac Niocaill, C., and Smethurst, M.A., 1994 Palaeozoic palaeogeography of Laurentia and its margins: a reassessment of palaeomagnetic data: Geophysical Journal International, v. 116 p. 715-725, doi: 10.1111/j.1365-246X.1994. tb03292.x.

Marillier, F.J.Y., ed., 1993, Tectonics of the Maritime Basin: Atlantic Geology, v. 29, p. 179-270.

Middleton, M., Keppie, J.D., Murphy, J.M., Miller, B.V. and Nance, R.D., 2007, P-T-t constraints on exhumation following subduction in the Rheic Ocean: Eclogitic Asis Lithodeme, Piaxtle Suite, Acatlán Complex, southern Mexico, in Linnemann, $U$. Nance, R.D., Kraft, P., and Zulauf, G., eds., The evolution of the Rheic Ocean: From AvalonianCadomian active margin to Alleghenian-Variscan collision: Geological Society of America Special Paper 423, p. 489-509.

Miller, B.V., Dostal, J., Keppie, J.D., Nance, R.D., Ortega-Rivera, A and Lee, J.K.W., 2007 Ordovician calc-alkaline granitoids in the Acatlán Complex, southern México: Geochemical and geochronologic data and implications for the tectonics of the Gondwanan margin of the Rheic Ocean, in Linnemann, U., Nance, R.D., Kraft, P. and Zulauf, G., eds., The evolution of the Rheic
Ocean: From Avalonian-Cadomian active margin to Alleghenian-Variscan collision: Geological Society of America Special Paper 423, p. 465-475.

Morris, R.C., 1989, Stratigraphy ad sedimentary history of post-Arkansas Novaculite Carboniferous rocks of the Ouachita Mountains, in Hatcher, R.D., Jr., Thomas, W.A., and Viele, G.W., eds., The Appalachian-Ouachita Orogen in the United States: Boulder, Colorado, The Geological Society of America, Geology of North America, v. F-2, p. 591-602.

Murphy, J.B., and Nance, R.D., 2008, The Pangea conundrum: Geology, v. 36, p. 703-706, doi: 10.1130/G24966A.1.

Murphy, J.B., Gutierrez-Alonso, G., Nance, R.D., Fernandez-Suarez, J., Keppie, J.D., Quesada, C., Strachan, R.A., and Dostal, J., 2006, Origin of the Rheic Ocean: Rifting along a Neoproterozoic suture?: Geology, v. 34, p. 325-328, doi: 10.1130/ G22068.1.

Nance, R.D., Murphy, J.B., and Keppie, J.D., 2002, A Cordilleran model for the evolution of Avalonia: Tectonophysics, v. 352, p. 11-31, doi: 10.1016/ S0040-1951(02)00187-7.

Nance, R.D., Miller, B.V., Keppie, J.D., Murphy, J.B. and Dostal, J., 2007, Vestige of the Rheic Ocean in North America: The Acatlán Complex of southern México, in Linnemann, U. Nance, R.D. Kraft, $P$., and Zulauf, G., eds., The evolution of the Rheic Ocean: From Avalonian-Cadomian active margin to Alleghenian-Variscan collision: Geological Society of America Special Paper 423, p. 437-452.

Nance, R.D., Murphy, J.B., Strachan, R.A., Keppie, J.D., Gutiérrez-Alonso, G., Fernández-Suárez, J. Quesada, C. Linnemann, U., D'Lemos, R., and Pisarevsky, S.A., 2008, Neoproterozoic-early Paleozoic tectonostratigraphy and palaeogeography of the peri-Gondwanan terranes: Amazonian v. West African connections, in Ennih, $\mathrm{N}$, and Liégeois, J-P., eds., The boundaries of the West African Craton: Geological Society [London] Special Publication 297, p. 345-383.

Nutman, A.P., Green, D.H., Cook, C.A., Styles, M.T. and Holdsworth, R.E., 2001, SHRIMP U/Pb zircon dating of the exhumation of the Lizard Peridotite and its emplacement over crustal rocks, Cornwall, England: Constraints for tectonic models: Journal of the Geological Society, v. 158, p. $825-836$.

Pickering, K.T., 2008, The destruction of lapetus and Tornquist's Oceans: Geology Today, v. 5, p. 160166, doi: 10.1111/j.1365-2451.1989.tb00655.x.

Pickering, K.T., and Smith, A.G., 1995, Arcs and backarc basins in the Lower Palaeozoic circum-Atlantic: The Island Arc, v. 4, p. 1-67, doi: 10.1111/ j.1440-1738.1995.tb00132.x.

Piqué, A., and Skehan, J.W., 1992, Late Paleozoic orogenies in western Africa and eastern North America: The diachronous closure of the Theic Ocean: Tectonics, v. 11, p. 392-404, doi: 10.1029/ 91TC01606.

Prigmore, J.K.,Butler, A.J., and Woodcock, N.H., 1997, Rifting during separation of Eastern Avalonia from Gondwana: Evidence from subsidence analysis: Geology, v. 25, p. 203-206, doi: 10.1130/00917613(1997)025<0203:RDSOEA > 2.3.CO;2.

Quesada, C., Fonseca, P., Munha, J., Oliveira, J.T., and Ribeiro, A., 1994, The Beja-Acebuches Ophiolite (Southern Iberia Variscan Fold Belt): Geological characterization and geodynamic significance: Boletín Geológico y Minero, v. 105, p. 3-49.

Samson, S.D., 2001, Timing of Alleghanian magmatism revisited: Geological Society of America Abstracts with Programs, v. 33, no. 2, p. 7.

Sánchez-García, T., Bellido, F., and Quesada, C., 2003, Geodynamic setting and geochemical signatures of Cambrian-Ordovician rift-related igneous rocks (Ossa-Morena Zone, SW Iberia): Tectonophysics, v. 365 , p. 233-255, doi: 10.1016/S0040-1951 (03)00024-6

Sánchez-Martínez, S., Arenas, R. García, F.D. Martínez Catalan, J.R., Gómez-Barreiro, J., and Pearce, J.A., 2007, Careón ophiolite, NW Spain:
Suprasubduction zone setting for the youngest Rheic Ocean floor: Geology, v. 35, p. 53-56, doi: 10.1130/G23024A.1.

Thorogood, E.J., 1990, Provenance of the pre-Devonian sediments of England and Wales: $\mathrm{Sm}-\mathrm{Nd}$ isotopic evidence: Journal of the Geological Society, v. 147, p. 591-594, doi: 10.1144/ gsjgs.147.4.0591.

Van der Voo, R., 1988, Paleozoic paleogeography of North America, Gondwana, and intervening displaced terranes: Comparisons of paleomagnetism with paleoclimatology and biogeographical patterns: Geological Society of America Bulletin, v. 100, p. 311-324, doi: 10.1130/0016-7606 (1988) $100<0311$ :PPONAG > 2.3.CO;2.

van Staal, C.R., Dewey, J.F., Mac Niocaill, C., and McKerrow, W.S., 1998, The Cambrian-Silurian tectonic evolution of the Northern Appalachians and British Caledonides; history of a complex, west and southwest Pacific-type segment of lapetus, in Blundell, D., and Scott, A.C. eds., Lyell: The past is the key to the present: Geological Society [London] Special Publication 143, p. 199-242.

Vega-Granillo, R., Talavera-Mendoza, O., MezaFigueroa, D., Ruiz, J., Gehrels, G.E., and LópezMartínez, M., 2007, Pressure-temperature-time evolution of Paleozoic high-pressure rocks of the Acatlán Complex (southern Mexico): Implications for the evolution of the lapetus and Rheic Oceans: Geological Society of America Bulletin, v. 119, p. 1249-1264, doi: 10.1130/B226031.1.

Viele, G.W., and Thomas, W.A., 1989, Tectonic synthesis of the Ouachita orogenic belt, in Hatcher, R.D., Jr., Thomas, W.A., and Viele, G.W., eds. The Appalachian-Ouachita orogen in the United States: Boulder, Colorado, The Geological Society of America, Geology of North America, v. F-2, p. 695-728.

Winchester, J.A , Pharoah, TC, and Verniers, J., 2002 Palaeozoic amalgamation of Central Europe: An introduction and synthesis of new results from recent geological and geophysical investigations, in Winchester J.A. Pharoah, T.C, and Verniers, J., eds., Palaeozoic Amalgamation of Central Europe: Geological Society [London] Special Publication 201, p. 1-18.

Wintsch, R.P., Kunk, M.J., Boyd, J.L., and Aleinikoff, J.N., 2003, P-T-t paths and differential Alleghanian loading and uplift of the Bronson Hill terrane, south central New England: American Journal of Science, v. 303, p. 410-446, doi: 10.2475/ ajs.303.5.410

Woodcock, N.H., Soper, N.J., and Strachan, R.A., 2007 A Rheic cause for the Acadian deformation in Europe: Journal of the Geological Society, v. 164, p. 1023-1036, doi: 10.1144/0016-76492006-129.

Wortman, G.L., Samson, S.D., and Hibbard, J.P., 1998 Precise timing constraints on the kinematic development of the Hyco Shear Zone-Implications for the Central Piedmont Shear Zone, southern Appalachian orogen: American Journal of Science, v. 298, p. 108-130.

Manuscript received 12 July 2008; accepted 16 October 2008.

\section{Recommended Reading}

\section{GSA Special Paper 423: \\ The Evolution of the Rheic Ocean: \\ From Avalonian-Cadomian Active Margin \\ to Alleghenian-Variscan Collision \\ U. Linnemann, R.D. Nance, P. Kraft, and $G$. Zulauf, eds.}

Member price: $\$ 115.00$ | Non-Member: $\$ 149.00$ ISBN: 978-0-8137-2423-2

THE GEOLOGICAL SOCIETY OF AMERICA ${ }^{\circledR}$

www.geosociety.org/bookstore 